\title{
Tritium activity trend formation in groundwater of Quaternary aquifer system, south-eastern Lithuania
}

\section{Vytautas Samalavičius,}

\section{Robert Mokrik}

Vilnius University,

M. K. Čiurlionio St. 21/27,

LT-03101 Vilnius

E-mail:vytautas.samalavicius@gmail.com; robert.mokrik@gf.vu.lt
Samalavičius V., Mokrik R. Tritium activity trend formation in groundwater of Quaternary aquifer system, south-eastern Lithuania. Geologija. Geografija. 2016. T. 2(4). ISSN 2351-7549.

Radioactive decay and mixing leads to tritium activity decrease in groundwater. In south-eastern Lithuania, the unconfined layer and precipitation water tritium activity decrease rate is dominated by radioactive decay for the period of 1980-2013. Confined aquifers are vastly affected by mixing; therefore, it is hard to predicted tritium activity values. To achieve it, the monitoring type of sampling must be applied in order to calculate tritium activity gradient value. Moreover, gradient values in different sampling points along the water pathway must be similar. It is a necessary condition when comparing theoretical decay curves with actually calculated. Only the shallowest confined aquifer (ag II-III $m d$-gr) in this study met these conditions. An additional method for modelled data interpretation was tritium peak analysis. According to the modelled tritium peak, a few possible dating water age alternatives exist. The data analysis suggests that no certain water age could be determined. The tritium peak analysis could be a helpful method to gain more comprehensive and valuable hydrogeological information.

Keywords: tritium activity $(a T)$, tritium gradient $\left(T_{\text {grad. }}\right)$, groundwater dating, Quaternary aquifer system, south-eastern Lithuania

\section{INTRODUCTION}

The largest part of tritium in groundwater is anthropogenic in origin. The source of tritium is thermonuclear bomb testing in the upper atmosphere during 1954-1964 period (Clark, Fritz, 1997). In the atmosphere, tritium is being oxidized forming tritium water (THO or ${ }^{3} \mathrm{HHO}$ ) (Canadian Nuclear Safety Commission, 2009). Therefore, tritium does not participate during chemical reactions and is introduced into the global hydrological cycle. As anthropogenic tritium spreads globally, precipitation constantly recharges groundwater, thus ${ }^{3} \mathrm{H}$ could be used as a tracer. At present, groundwater dating using tritium is hardly possible, because initial tritium activity values usually exist just for short time intervals. In addition, water mixing strongly affects the tritium signal. Groundwater age could only be a matter of agreement because old water constantly mixes with younger thus accurate age cannot be determined. Interpretation of tracer data includes box models such as the piston flow model (PFM), exponential model (EM), linear model (LM) and various mixed type models (Kinzelbachet et al., 2002; Maloszewski, Zuber, 1996). Each of these models has strict limitations and incorporates a few parameters. In the piston flow model, there is an assumption that there are no flow lines with different transient times. Hydrodynamic dispersion and molecular diffusion are being neglected in PFM (Maloszewski, Zuber, 1996). Exponential model approximation involves distribution of transient times. Initial concentration of the tracer is calculated as mass of the injected tracer diluted in the volume of the whole 
system. According to this model no mixing occurs between flow lines. The only location for mixing is at the sampling point. The mean transit time is the only parameter of EM (Kinzelbachet et al., 2002; Maloszewski, Zuber, 1996). The linear model is similar to the exponential model - no mixing takes place between flow lines. The flow lines have the same velocity, but linearly increasing flow time (Maloszewski, Zuber, 1996). Due to small tritium values in samples, these models cause considerable uncertainties. In case of dating groundwater which has small $(<15 \mathrm{TU})$ tritium values, water turns out to be older than it is determined by other modelling methods (Mokrik et al., 2012). Tritium activity values which are below the background concentrations usually means that groundwater is older than 60 years and no hydrogen bomb tritium is present in the aquifer. Despite the recharge of modern water, tritium values could be low if the model has a big dispersion parameter (Maloszewski, Zuber, 1996). Thus the mean water age alone is not sufficient for groundwater dating and describing the formation process. Moreover, lack of data itself makes it hard to interpret and calculate precise tritium trend formation during time.

In this study tritium was considered to be a tracer. Several different tritium peak analysis alternatives are presented in this article along with the gradient method. It could be used to describe the past and future tritium activity of a specific aquifer.

The studied cross-section includes one unconfined and five confined aquifers. These aquifers were formed during Quaternary chronostratigraphical events: Dzūkija-Dainava (Waalian interglacial, $a g$ II $d z-d n$ ), Dainava-Žemaitija (Holsteinian interglacial, ag II $d n-z ̌ m)$, Žemaitija-Medininkai (Drenthian-Warthian interglacial, ag II žm-md), Medininkai-Grūda (Eemian-Middle Weichselian interglacial/interstadial, $a g$ II-III md-gr), Grūda-Baltija (Upper Weichselian interstadial, ag III $g r-b l$ ) (Mokrik et al., 2012). Two aquifers were added to other, more significant in amount, aquifers: locally spread ag III bl-gr and ag II $d z-d n$ stratons combined with, respectively, ag II-III $m d-g r$ and ag II $\check{z} m$ - $d n$ (Mokrik et al., 2012). The shallowest confined aquifer is ag II-III $m d-g r$, the second one is ag II žm-md and the third is ag II dn-žm which are separated with semi-permeable aquitards. The crosssection represents the full path of groundwater from recharge to discharge areas (Mokrik et al., 2012). The numbering starts with the first aquifer and proceeds from the recharge area: ag II-III $m d-g r-1-4$ points, ag II žm-md - 5-7 points, ag II dn-žm - 8-11 points. Additional sample points (12-20) were taken in the year 2013 from wells located near the earlier ones (Tables 3, 4). The ag II-III md-gr aquifer spreads locally, but is linked hydraulically to the entire groundwater path. Its area covers $8,570 \mathrm{~km}^{2}$ (Fig. 1).

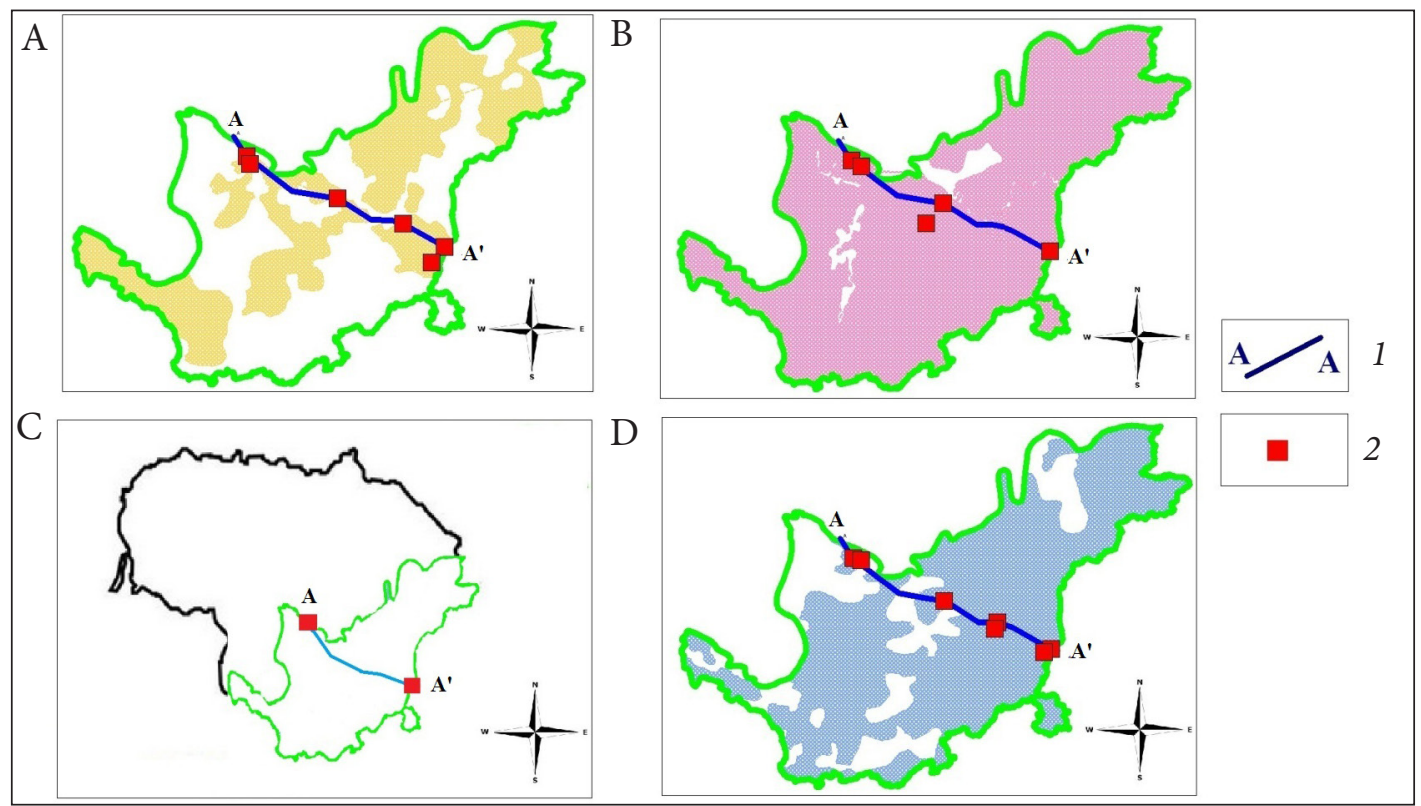

Fig. 1. Locations of aquifers (Mokrik et al., 2012): A - Medininkai-Grūda (ag II-III md-gr), B - Žemaitija-Medininkai ( $\operatorname{g}$ II $\check{z} m$-md), C - south-eastern Lithuania Quaternary aquifer system, D - Dainava-Žemaitija (ag II žm-dn). 1 - cross-section line, 2 - sampling sites 
Aquifers ag II žm-md $\left(15,600 \mathrm{~km}^{2}\right)$ and $a g$ II $d n$-žm $\left(12,360 \mathrm{~km}^{2}\right)$ spread along almost the entire southeastern Lithuania region (Fig. 1) (Mokrik et al., 2012). Hydrogeological stratons represented in cross-section are schematized to solid layers, ignoring disruptions (Fig. 2).

The hydrogeological structure strongly depends on ground surface relief. Lowlands descend and reach ag II $\check{z} m$-md aquifer. Vilnius is located in such a situation. The ag II-III $m d$-gr and ag II $\check{z} m$-md aquifers exist in Vilnius, but due to a complicated situation, these layers were approximated into one, including an unconfined layer (Figs. 1, 2). The segments of landscape from Vilnius to Vievis are wavy, altitude amplitude is up to $50 \mathrm{~m}$. The other section (Vievis-Kaunas) of the landscape descends evenly. Land surface (aquifers analogically) descends in distal direction from the recharge area. This situation determines water flow direction and hydraulic head gradient. All aquifers are above sea level, so they discharge into the basins of Neris and Nemunas rivers.

\section{METHODS}

During fieldworks, samples for tritium analysis were selected only from constantly exploitable wells. Water was extracted using submersible pumps for about $15 \mathrm{~min}$ before sampling. Samples were stored in 1 litre (PET) bottles.

Tritium analysis was done at Nature Research Centre, Laboratory of Nuclear Geophysics and Radioecology, using a liquid scintillation counting spectrometer Tri-Carb $3170 \mathrm{Tr} / \mathrm{Sl}$, previously enriching the samples (Mažeika, 2007).

Tritium trend analysis is a complex process based on statistical data of global and Lithuanian tendencies through time, correlation of measured and theoretical results. Using earlier research and available databases, a graph was compiled (Fig. 3). It included tritium activity changes during the period 1980-2012. The graph includes unconfined and three confined aquifers, precipitation in Ottawa (Canada), Vienna (Austria) and Ignalina (Lithuania) (Mokrik, Mažeika, 2006;

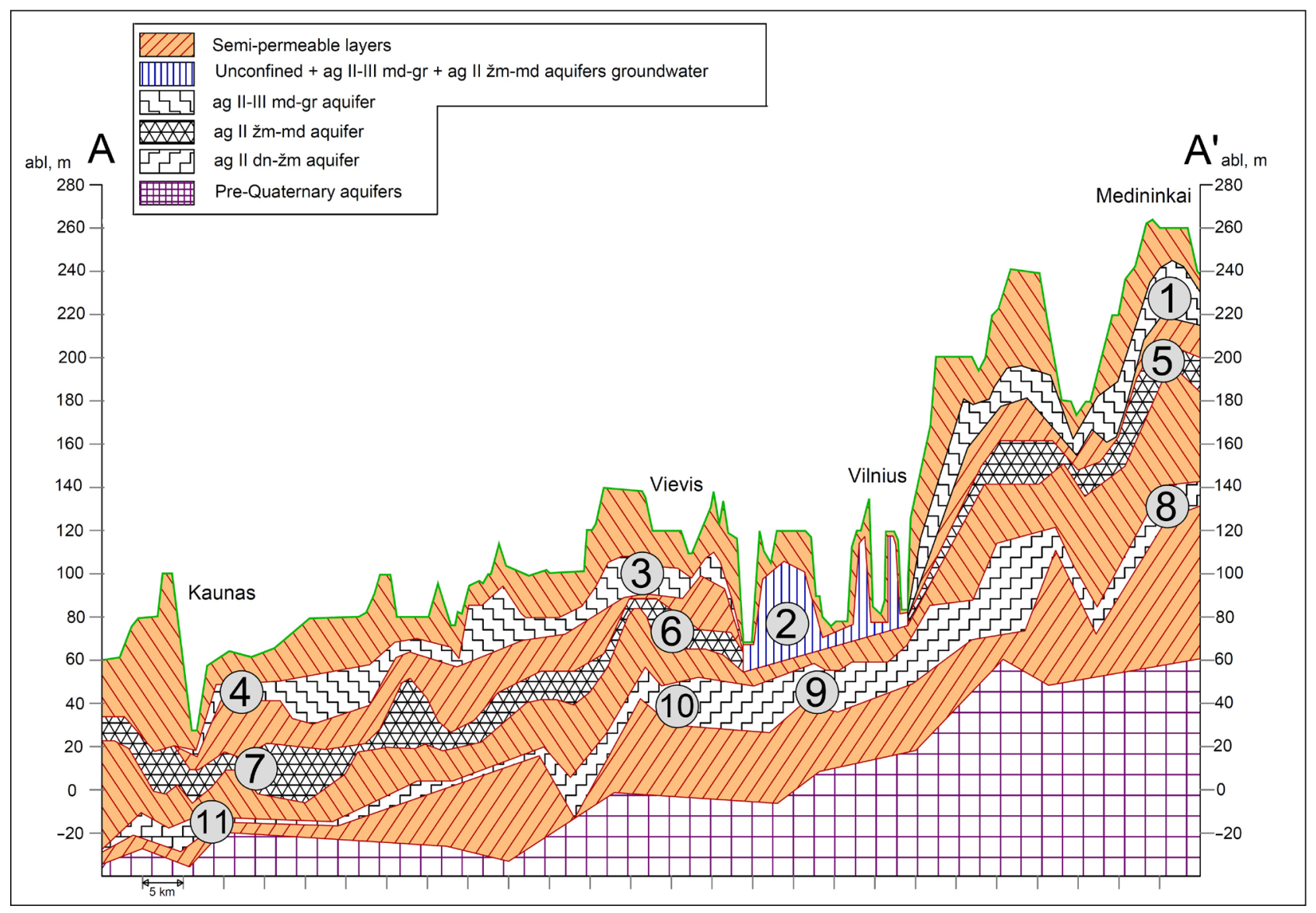

Fig. 2. A-A' cross-section of schematized hydrogeological stratons. Vertically - altitude in meters, horizontal steps - distance (1 step - 5 kilometres). The sampling sites indicated by numbers in filled dots 


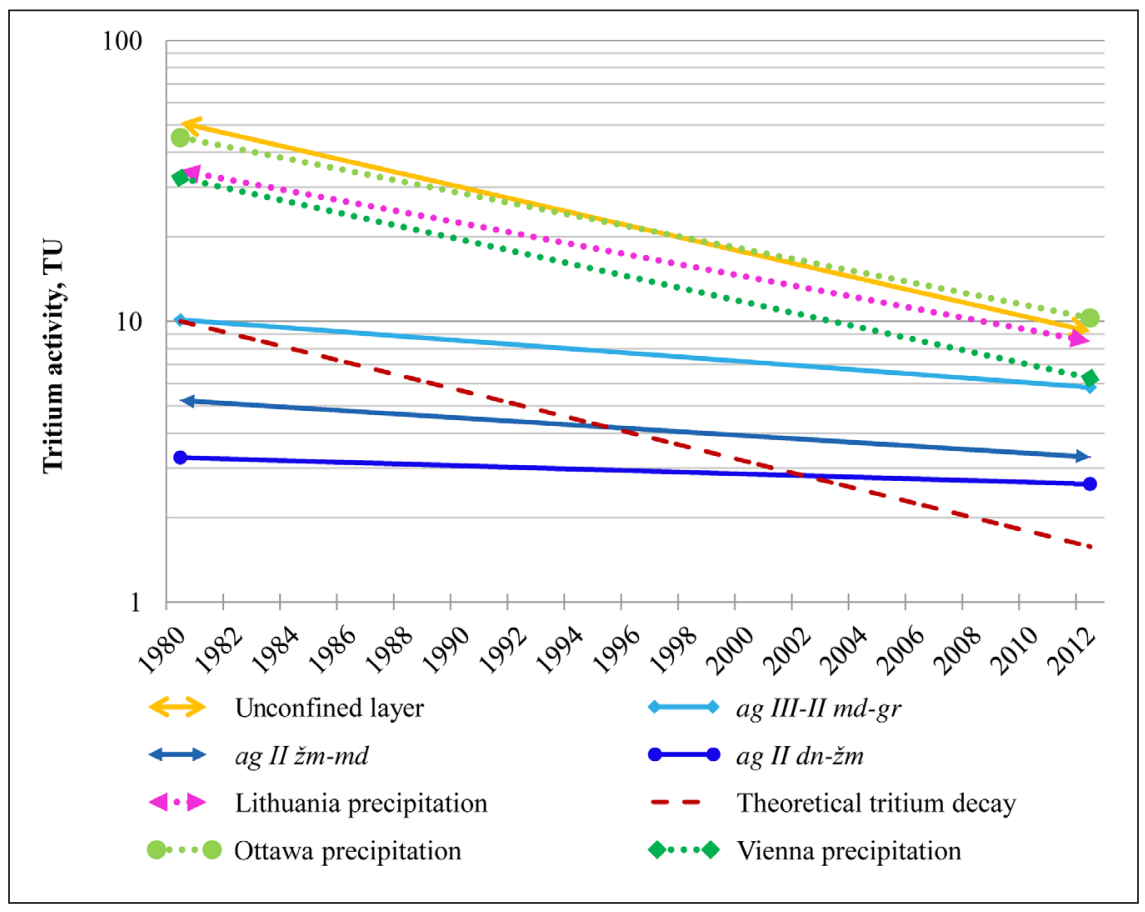

Fig. 3. Tritium activity decrease in precipitation and groundwater exponential trend lines during the period of 1980-2012 (Juodkazis et al., 1995; Clark, Fritz, 1997; Petrošius, 1990)

Juodkazis, Mažeika, Petrošius, 1995; Clark, Fritz, 1997; Petrošius, 1990).

The tritium volumetric activity trend in precipitation, after thermonuclear device detonation, shows cumulative increase of concentration in the atmosphere until 1964-1965. Later, rapid decrease is observed. It could happen due to planetary air mass dilution and dispersion until the year 1980. Since then, tritium activity decrease tendency in precipitation is based on the radioactive decay process (activity less than $100 \mathrm{TU}$ ). It will stop when the background, natural tritium activity, level will be reached. Therefore, after 1980 precipitation and unconfined groundwater tritium activity trends must be identical.

Tritium peak analysis in groundwater before 1980 needs either actual values from 1953 or modelling data. Modelling results show anthropogenic tritium peaks in different aquifers (Fig. 4). Every peak, because of its specific shape, needs individual analysis. It is a more appropriate way to describe groundwater behaviour than groundwater dating. A few possible alternatives are presented in this study: start residence time, peak formation time and others. It shows that no real groundwater age could be specified.
Peak analysis, after it reaches its maximum, could be accomplished using the gradient method. Theoretical tritium decay gradient curves were created using different initial tritium activity $\left(a T_{0}=30,40,50,60,70 \mathrm{TU}\right)$. To determine tritium decrease gradient in the aquifer at least a few sampling points must be selected. Two (or preferably more) separate measurements in one sampling point at different time is necessary for gradient calculation. Similar gradients in separate sampling points could mean that all aquifer water is in equilibrium with precipitation. The ag II-III $m d-g r$ aquifer satisfies this condition. Gradient value of Medininkai-Grūda aquifer was applied on the graph with theoretical gradient curves (Fig. 5). Using the best fitting theoretical curve, tritium activity can be predicted for the future (until background value) or reconstructed for the past (until maximum titium activity) in a specific aquifer. $t$ - time, $a T$ - tritium activity, $\alpha_{0} T$ - initial tritium activity, $T_{\text {grad. }}$ - tritium gradient in time:

$$
\begin{aligned}
& T_{\text {grad. }}=\frac{\alpha_{0} T-\alpha_{t} T}{t} \\
& a T=\alpha_{0} T \times e^{-t / 17.93}
\end{aligned}
$$




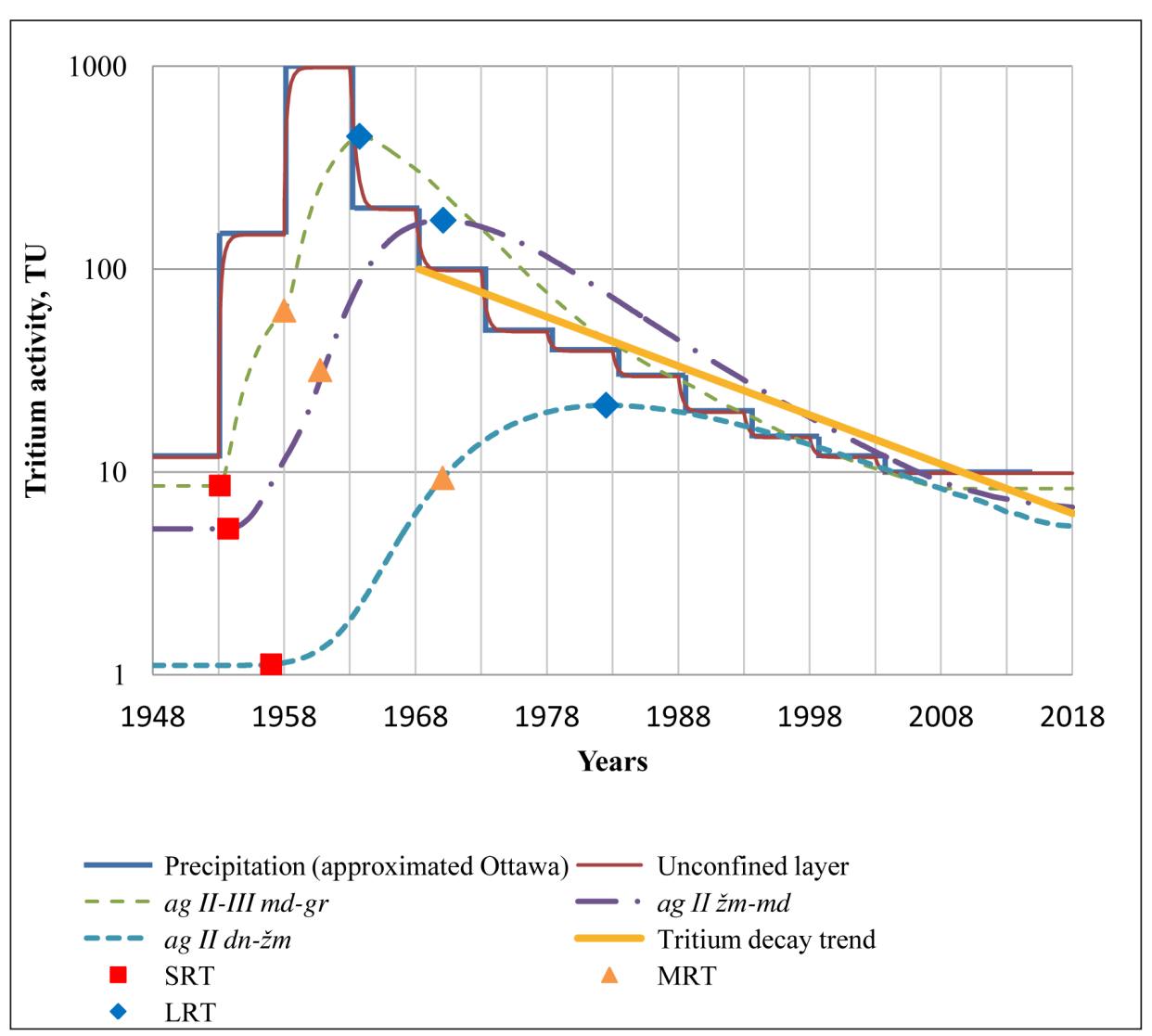

Fig. 4. Modelling results of tritium activity alteration during the period of 1948-2018 - example of Medininkai

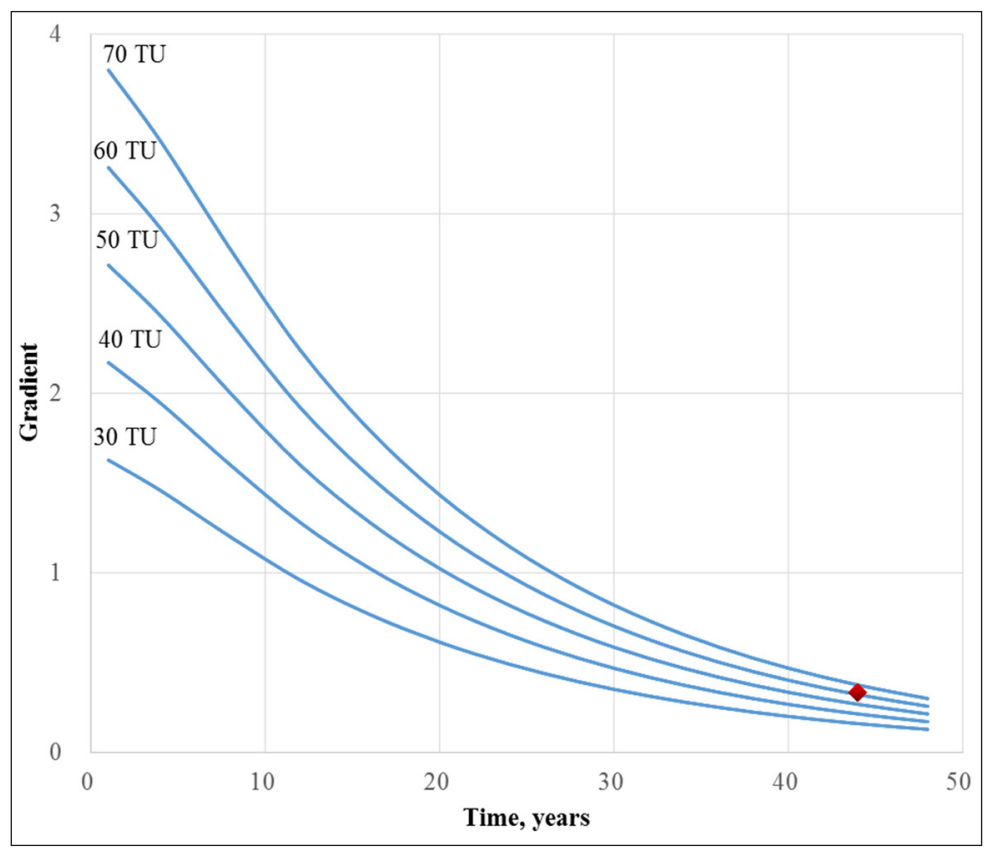

Fig. 5. Tritium decay gradient in time (step - 4 years) compared to the measured and calculated gradient value of ag II-III $m d-g r$ aquifer. Labels represent initial tritium activity values for gradient calculation

\section{DISCUSSION}

Decrease of tritium activity in the aquifer depends on two main factors: isotopic decay and mixing. Figure 3 shows approximate trends of tritium activity in precipitation (Ottawa, Vienna and Vilnius) and in groundwater (three confined and one unconfined layers). Trends represent average values of tritium activity based on statistical data collected since 1980. Precipitation trends inclination, in comparison with the radioactive decay line, are similar. It means that activity decrease rate is mainly determined by tritium decay in the atmosphere. Absolute activity values are 
different (Ottawa - highest tritium activity, Vienna - lowest, and Vilnius is in the middle). This inequality could come from heterogenic tritium distribution in the atmosphere. It led to differences in precipitation water activity around the globe. Unconfined layer groundwater activity trend shows an inclination similar to the radioactive decay line, but absolute values are greater than in precipitation. Accumulation of tritium in unconfined aquifer groundwater appeared because the circulation rate in the hydrogeosphere is much slower than in the atmosphere. A significant drop in tritium concentration in the atmosphere occurred because of global air mass mixing and dilution (before year 1980) (Clark, Fritz, 1997). Groundwater in the unconfined layer is equilibrated with precipitation; tritium decrease rate is determined by radioactive decay. The unconfined aquifer is recharged with modern $(<60$ years) water. Confined aquifers tritium activity trend inclination is smaller (according to the ordinate axis). It means that tritium reached the aquifers, but equilibrium with precipitation did not settle. Absolute tritium activity values decrease according to the depth of the aquifer. However, Fig. 3 represents statistical data of all south-eastern Lithuania regions and in some places confined aquifers can be equilibrated with precipitation, for example, recharge area (Fig. 4). The modelling results of tritium activity of the Quaternary system in south-eastern Lithuania are shown in Fig. 4, period of 1955-2014. Pre cipitation is represented in green line and modelled using Ottawa precipitation trend. Unconfined layer groundwater reacts to precipitation almost instantly (about 1 year delay). Confined aquifers tritium activity peaks come later. Analyzing the tritium signal as a tracer makes more logical and accurate conclusions than dating. Tritium peak in every aquifer could be described using such parameters as (Table 1):

- start residence time (SRT) - time from beginning of tracer injection to peak formation start,

- middle residence time (MRT) - time from beginning of tracer injection to peak formation halfway,

- largest (maximum) residence time (LRT) - time from beginning of tracer injection to peak formation end,

- peak formation time (PFT) - time from peak formation start to its maximum value,

PFT $=$ LRT - SRT,

- background "prebomb" tritium activity - value of natural tritium activity in groundwater.

SRT, MRT, LRT and PFT present different stages of peak formation, but no certain water age could be determined. Since groundwater is being recharged by precipitation constantly, mixing makes accurate dating impossible. The modelled values of "prebomb" tritium activity in the aquifer are considered to be a baseline of peaks (Fig. 4). It gives a possibility to determine the quantity of anthropogenic tritium in the aquifer at a specific moment of time. These parameters could be used to gain more detailed hydrogeological information about groundwater circulation, recharge and discharge peculiarities. For example, SRT shows minimal flow time from precipitation event to recharge of the aquifer in a particular location, LRT would accordingly represent maximum flow time,

Table 1. Peak description parameters based on the modelling results

\begin{tabular}{|c|c|c|c|c|c|c|}
\hline Location & Aquifer & $\mathrm{SRT}^{\star}, \mathrm{y}$ & MRT, y & LRT, y & PFT, y & "Prebomb" tritium activity, TU \\
\hline \multirow{3}{*}{ Medininkai } & $g r-m d$ & 1 & 5 & 11 & 10 & 8.5 \\
\hline & $m d-\check{z} m$ & 2 & 8 & 15 & 13 & 5.1 \\
\hline & $\check{z} m-d n$ & 7 & 17 & 30 & 23 & 1.1 \\
\hline \multirow[t]{2}{*}{ Vilnius } & $\frac{g r-m d}{m d-\check{z} m}$ & 2 & 13 & 25 & 23 & 3.5 \\
\hline & $\check{z} m-d n$ & 9 & 18 & 32 & 23 & 0.8 \\
\hline \multirow{3}{*}{ Vievis } & $g r-m d$ & 8 & 30 & 53 & 45 & 0.4 \\
\hline & $m d-\check{z} m$ & 17 & 35 & 54 & 37 & 0.2 \\
\hline & $\check{z} m-d n$ & 24 & 17 & 55 & 31 & 0.05 \\
\hline \multirow{3}{*}{ Kaunas } & $g r-m d$ & 1 & 5 & 10 & 9 & 6 \\
\hline & $m d-\check{z} m$ & 5 & 19 & 34 & 29 & 0.1 \\
\hline & žm-dn & - & - & - & - & $<0.0001$ \\
\hline
\end{tabular}

* SRT - start residence time, MRT - middle residence time, LRT - largest residence time, PFT - peak formation time. 
PFT could be a parameter of water circulation in the aquifer itself (avoiding time necessary for water to reach the aquifer). These parameters are analogical to tracer experiment data, so theoretically aquifer parameters (such as effective porosity) could be calculated. Additional data would be required for this procedure.

Equilibrium between precipitation and groundwater in the aquifer could be identified comparing theoretical and measured tritium values. It requires a few (at least two) measurements at a particular point of a specific aquifer. Examples of sampling are shown in Table 2. Additional sampling points located near the cross-section are presented in Table 3.

An example of aquifer ag II-III md-gr shows parallel decrease rate (gradient) which leads to the conclusion that equilibrium between this aquifer and precipitation became prevalent. Radioactive decay factor dominates the decrease rate of tritium activity in Medininkai-Grūda aquifer. Using equation 2 , theoretical tritium activity values for year 2012 were calculated using the measured value of 2008 as initial tritium activity and taking a fouryear decay period. Results are presented in Table 4. Theoretical values resemble actual, in the range of uncertainties of measuring procedure.

At least two, separate in time, samples must be taken and analyzed in one location (sampling point). The gradient was calculated using equation 1 . The calculated gradient values are presented in Table 2. The gradient values of ag II-III md-gr aquifer are similar. The tritium activity gradient
Table 3 . Additional tritium activity values measured in 2013 near the cross-section

\begin{tabular}{|c|c|c|c|}
\hline Well No. & $\begin{array}{c}\text { Well } \\
\text { depth, } \mathrm{m}\end{array}$ & Location & $\begin{array}{c}{ }^{3} \mathrm{H} \text { volumetric } \\
\text { activity, TU }\end{array}$ \\
\hline \multicolumn{3}{|c|}{ ag II-III md-gr } & 2013 \\
\hline $40000 / 12$ & 30 & Medininkai & 6.9 \\
\hline $44346 / 13$ & 30 & Vilnius $^{\star}$ & 2.9 \\
\hline $27850 / 14$ & 20 & Kaunas & $<0.2$ \\
\hline \multicolumn{4}{|c|}{ ag II žm-md } \\
\hline $41638 / 15$ & 60 & Medininkai & 7.0 \\
\hline $37232 / 16$ & 117 & Vievis & $<0.2$ \\
\hline $29331 / 17$ & 87 & Kaunas & 1.6 \\
\hline \multicolumn{4}{|c|}{$a g I I d n-\check{z} m$} \\
\hline $44345 / 19$ & 45 & Vilnius & 0.9 \\
\hline $4951 / 20$ & 120 & Kaunas & 2.2 \\
\hline
\end{tabular}

values of ag II $\check{z} m$-md and ag II $d n-\check{z} m$ aquifers are different along the groundwater path. The graph (Fig. 4) with theoretical decay gradient curves was plotted using initial tritium activities (30, 40, $50,60,70 \mathrm{TU})$. The starting point in time is year 1963 when maximum tritium values were detected in precipitation. The actual tritium gradient point is placed on theoretical curves depending on time elapsed after tritium peak in precipitation. Aquifer ag II-III $m d$-gr coincides with the theoretical curve of initial activity value 60 TU. Following this curve it is possible to forecast how tritium concentration changed in a specific aquifer during time. However, the theoretical curve represents only decay. Mixing along with recharge time was not taken

Table 2. Tritium activity values measured in 2008 and 2012 along the cross-section

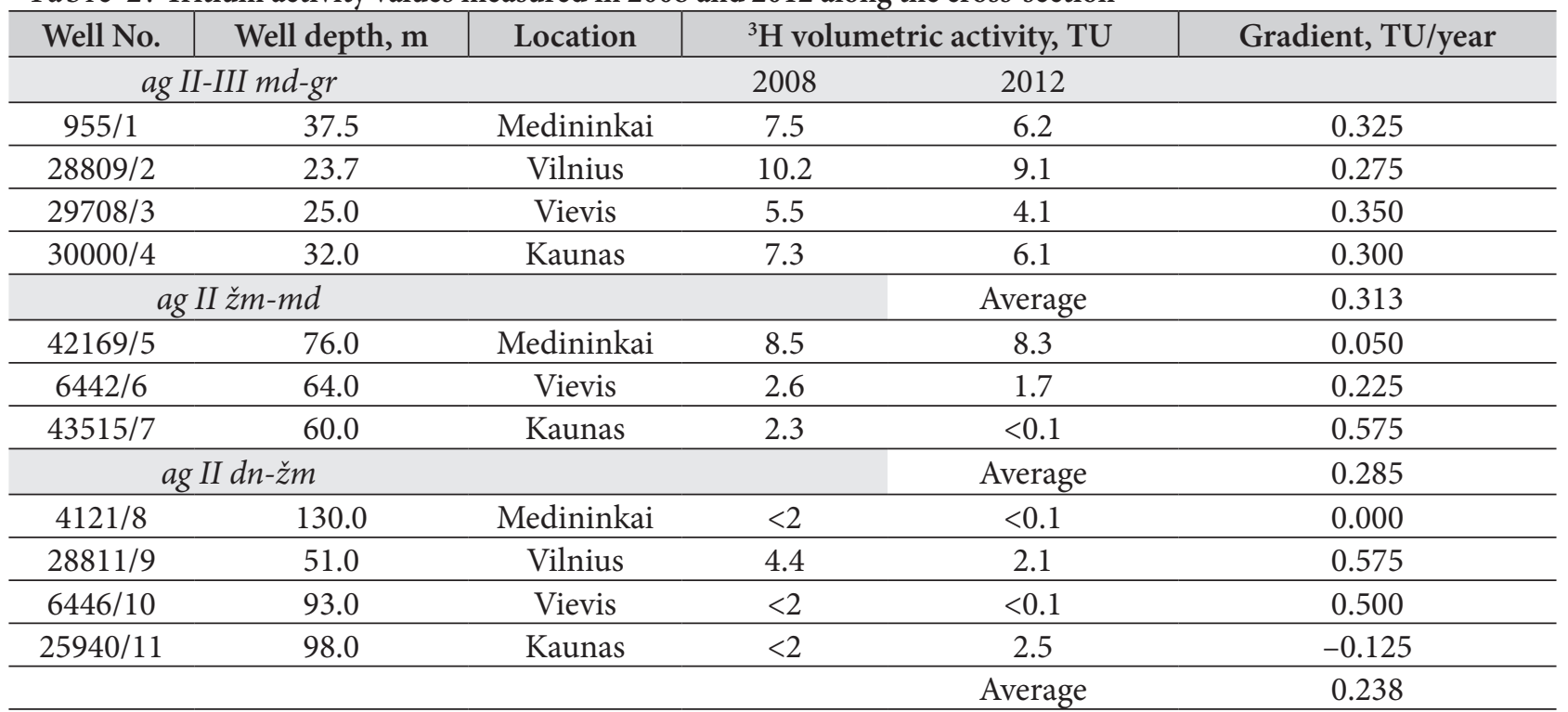


Table 4. The ag II-III $m d$ - $g r$ aquifer groundwater tritium data compared to tritium decay values (2008 - initial activity, period -4 years)

\begin{tabular}{c|c|c|c|c|c|c}
\hline & & & \multicolumn{5}{c}{${ }^{3}$ H volumetric activity, TU } \\
Well No. & Well depth, $\mathbf{m}$ & Location & $\begin{array}{c}2008 \\
\text { measured }\end{array}$ & $\begin{array}{c}2012 \\
\text { theoretical }\end{array}$ & $\begin{array}{c}2012 \\
\text { measured }\end{array}$ & Uncertainty, \pm \\
\hline \multicolumn{7}{c|}{ Medininkai-Grūda } \\
\hline $955 / 1$ & 37.5 & Medininkai & 7.5 & 6.1 & 6.2 & 0.4 \\
\hline $28809 / 2$ & 23.7 & Vilnius & 10.2 & 8.2 & 9.1 & 0.6 \\
\hline $29708 / 3$ & 25 & Vievis & 5.5 & 4.4 & 4.1 & 0.3 \\
\hline $30000 / 4$ & 32 & Kaunas & 7.3 & 5.9 & 6.1 & 0.4 \\
\hline
\end{tabular}

into account. Uncertainty depends on the time of prediction: the longer time the bigger uncertainty. This method requires additional information like statistical or modelling data. It could show the period when radioactive decay is a dominant factor in tritium decrease rate.

\section{CONCLUSIONS}

1. The statistical data of tritium activity analysis revealed that the unconfined layer of groundwater of south-eastern Lithuania is in equilibration with precipitation while confined aquifers are not (period 1980-2012).

2. At some specific points of Medininkai-Vilnius-Vievis-Kaunas cross-section, aquifer ag IIIII md-gr, groundwater tritium activity gradients show that the main factor of gradient decrease rate is radioactive decay. That enables to apply the gradient method and calculate initial tritium activity in the aquifer 42 years ago. Initial tritium activity Medininkai-Grūda is 60 TU.

3. The modelled tritium activity peaks in Medininkai recharge area could serve as an example of several dating possibilities. It leads to the conclusion that no certain water age could be determined. A more appropriate way is tritium peak analysis using these parameters (residence and peak formation time).

\section{ACKNOWLEDGEMENTS}

The authors of this article would like to express their gratitude to Dr. Anicetas Štuopis for help in organizing fieldworks and providing valuable data for this research. A great deal of acknowledgement also goes to Prof. Dr. habil. Jonas Mažeika and Dr. Rimantas Petrošius for sample analyses at the laboratory of Nature Research Centre, Vilnius, Lithu- ania. The authors are grateful to the reviewers Prof. Dr. habil. Jonas Mažeika and Dr. Jurga Arustienè. The study is coordinated and funded by the Vilnius University and IAEA research project CPR F33022. This support is gratefully acknowledged.

Received 13 October 2016 Accepted 14 November 2016

\section{References}

1. Investigation of the Environmental Fate of Tritium in the Atmosphere. 2009. Canadian Nuclear Safety Commission. Ottawa, Canada. 104 p.

2. Clark I., Fritz P. 1997. Environmental Isotopes in Hydrogeology. New York: Lewis Publishers. 328 p.

3. Juodkazis V., Mažeika J., Petrošius R. 1995. Radioizotopiniai metodai ekologinèje hidrogeologijoje. Geologija. 18: 1-132 [in Lithuanian].

4. Kinzelbach W., Aeschbach W., Alberich C., Goni I. B., Beyerle U., Brunner P., Chiang W.-H., Rueedi J., Zoellmann K. 2002. A Survey of Methods for Groundwater Recharge in Arid and Semi-arid Regions. Division of Early Warning and Assessment. United Nations Environment Programme. Nairobi, Kenya. 43 p.

5. Maloszewski P., Zuber A. 1996. Lumped parameter models for the interpretation of environmental tracer data. In: Manual on Mathematical Models in Isotope Hydrology. International Atomic Energy Agency. Vienna. 9-58.

6. Mažeika J. 2007. Tričio tūrinio aktyvumo vandens éminiuose įvertinimas. Vilnius: Geologijos ir geografijos institutas. $13 \mathrm{p}$.

7. Mokrik R., Mažeika J. 2006. Hidrogeochemija. Vilnius: Vilniaus universiteto leidykla. 248 p.

8. Mokrik R., Mažeika J., Juodkazis V., Štuopis A. 2012. The Quaternary deposits cross-section study by groundwater flow modeling and chemistry-isotope data, eastern part of Lithuania. Hydrogeology Journal. 22: 925-941.

9. Petrošius R. 1990. Tričio tyrimo metodika Baltijos aukštumu kvartero nuogulu požeminiame vandenyje: disertacija. $221 \mathrm{p}$. 
Vytautas Samalavičius, Robert Mokrik

\section{PIETRYČIŲ LIETUVOS KVARTERO VANDENINGOJO KOMPLEKSO POŽEMINIO VANDENS TRIČIO AKTYVUMO TRENDO FORMAVIMASIS}

Santrauka

Dèl XX a. antroje pusejje vykdytų termobranduolinių užtaisu bandymu i atmosferą pateko dideli kiekiai tričio, todèl išaugo ${ }^{3} \mathrm{H}$ koncentracija hidrosferoje. Šiuo metu tričio aktyvumas požeminiame vandenyje yra pasiekęs natūralias fonines reikšmes - antropogeninio ${ }^{3} \mathrm{H}$ signalas yra beveik išnykęs.

Atlikus tričio aktyvumo trendo analizę paaiškejjo, kad Pietryčių Lietuvos gruntinio vandens ${ }^{3} \mathrm{H}$ aktyvumas ir jo pokyčiai atitinka kritulių vandenị. Spūdiniuose sluoksniuose tričio aktyvumas yra veikiamas maišymosi. Pagrindinè problema analizuojant tričio signalą ir datuojant vandeni yra pradinių koncentracijų verčių trūkumas. Šias vertes galima apskaičiuoti naudojantis esamo signa- lo pokyčiu bėgant laikui, pasitelkus gradientų metodą. Ivertinant gradientą turi būti žinomos mažiausia dvi ${ }^{3} \mathrm{H}$ aktyvumo vertès, nustatytos viename taške, bet skirtingu laiku. Apskaičiuotos gradiento vertès taip pat turi sutapti keliose paèmimo vietose tiriamajame sluoksnyje. Šios sąlygos yra tenkinamos tik pirmame (ag II-III md-gr) spūdiniame sluoksnyje, kuriame pasiekta pusiausvyra tarp maitinančio gruntinio ir sluoksnyje esančio vandens.

Tričio aktyvumo smailès analize yra siūloma kaip modeliavimo rezultatų interpretavimo metodas. Vykstant nuolatiniam seno ir naujai patenkančio vandens maišymuisi, datavimas tampa sąlyginis ir atitinka sutartinị, vidutinị vandens amžių. Remiantis modeliuotu tričio aktyvumo kitimo grafiku parodoma, kad egzistuoja keli variantai, kuriais galima nusakyti vandens amžių. Tai suteikia išsamesnę ir detalesnę hidrogeologinę informaciją.

Raktažodžiai: tričio aktyvumas ( $a T)$, tričio gradientas $\left(T_{\text {grad. }}\right)$, požeminio vandens amžiaus nustatymas, kvartero vandeningas kompleksas, Pietryčių Lietuva 